Una revisión funcional al recurso de anulación de laudo en el Perú

\title{
Mario Reggiardo
}

En el presente artículo, el Profesor

Mario Reggiardo apoyado en doctrina y jurisprudencia analiza las normas que regulan el recurso de anulación de laudo arbitral. El autor evalúa las aproximaciones dogmáticas sobre si el recurso de anulación es un medio impugnatorio 0 un proceso impugnatorio.

Abogado por la Pontificia Universidad Católica del Perú, máster en Derecho y Economía por la Universidad de Hamburgo y profesor de Análisis Económico del Derecho y Derecho Procesal Civil en la Pontificia Universidad Católica del Perú, Universidad del Pacífico y Universidad Peruana de Ciencias Aplicadas.

El autor agradece el invalorable aporte de Brenda Gatica Saavedra en la investigación realizada para el presente trabajo. 


\section{Una revisión funcional al recurso de anulación de laudo en el Perú}

El Decreto Legislativo 1071 que norma el arbitraje en el Perú entró en vigencia el 1 de septiembre de 2008. Este trabajo intenta mostrar cómo se viene interpretando a la fecha las normas que regulan el recurso de anulación de laudo arbitral, tomando en cuenta temas de discusión en el medio académico peruano así como las sentencias del Tribunal Constitucional que han terminado de moldear la aplicación de esa institución en los últimos 5 años.

\section{El principio de inevitabilidad del arbitraje}

El Decreto Legislativo 1071 fue diseñado para que sea muy difícil que las partes que suscribieron el convenio arbitral, sometan sus controversias al Poder Judicial minimizando los efectos de dicho convenio. El Decreto Legislativo 1071 fue diseñado a partir del principio de inevitabilidad del arbitraje, que resulta un criterio de interpretación esencial para el inicio, desarrollo y ejecución del arbitraje en el Perú.

De acuerdo con Bullard ${ }^{1}$, el principio de inevitabilidad del arbitraje implica que ninguna acción u omisión de las partes debe impedir que el arbitraje se lleve a cabo. Esto se explica porque más allá de ser una declaración de las partes de someterse al arbitraje, el convenio arbitral es una es manifestación de voluntad de que las partes no buscan la participación del Poder Judicial en la solución de sus conflictos. Según Bullard, este principio, y por consiguiente la no intromisión judicial, tiene estas manifestaciones concretas $^{2}$ :

\subsection{Eliminación de la cláusula compromisoria}

Por muchos años el ordenamiento jurídico peruano hacía una distinción entre la cláusula compromisoria y el convenio arbitral ${ }^{3}$. La primera era un contrato preparatorio

1 Bullard G., Alfredo, "¿Qué fue primero: el huevo o la gallina? El Carácter contractual del recurso de anulación". En: Revista Internacional de Arbitraje, Julio - Diciembre 2013, p. 64.

2 Bullard G., Alfredo, "¿Qué fue primero: el huevo o la gallina? El Carácter contractual del recurso de anulación". En: Revista Internacional de Arbitraje, Julio - Diciembre 2013, p. 67.

3 El Código Civil de 1984 al inicio hacía una distinción entre la cláusula compromisoria y el compromiso arbitral. El artículo 1906, luego derogado por la Primera Disposición Final de Decreto Ley 25935, establecía que: "Las partes pueden obligarse mediante un pacto principal o una estipulación accesoria, a celebrar en el futuro un compromiso arbitral. En tal caso, no se requiere la designación de los árbitros. Es obligatorio fijar la extensión de la materia a que habrá de referirse el arbitraje. No es de aplicación a la cláusula compromisoria lo dispuesto en el artículo 1416". En cuanto al compromiso arbitral, el artículo 1909, derogado también por la Primera Disposición Final del Decreto Ley 25935, 
en el que las partes acordaban someterse a un arbitraje en caso surja algún tipo de controversia vinculada a su relación contractual; sin embargo, este acuerdo no era autoejecutable. Para que el arbitraje se inicie era necesario que las partes suscriban un segundo acuerdo, el llamado convenio arbitral, en el que se identificaba la controversia a solucionar, los árbitros, la ley aplicable, las reglas aplicables al arbitraje, etc.

El problema de esta distinción es que no tomaba en cuenta que los costos de transacción que permiten viabilizar ambos acuerdos eran distintos en uno u otro caso. Cuando se celebra un contrato es porque, usualmente, los costos de negociación entre las partes son lo suficientemente bajos como para que lleguen a un acuerdo, incluida la cláusula compromisoria. Sin embargo, cuando surge el conflicto, suele aumentar el costo de negociación por motivos como irritabilidad, desconfianza, resentimientos etc. En el Perú hay que sumarle a ello que la parte que consideraba que su probabilidad de ganar el caso era baja, se negaba a suscribir el convenio arbitral porque consideraba que esa probabilidad era más alta si litigaba en el Poder Judicial. La falta de precedentes vinculantes, la corrupción y la tasa de errores judiciales le generaban a la parte con baja probabilidad de éxito, un optimismo del que carecía en un arbitraje usualmente no vinculado a los defectos del Poder Judicial peruano ${ }^{4}$.

La negativa de una de las partes a celebrar el convenio arbitral, obligaba a su contraparte a recurrir al Poder Judicial para que el juez designe a los árbitros que conformarían el Tribunal, determine la materia arbitrable e incluso, decida la procedencia del arbitraje. Esta era una de las causas por las que el arbitraje era casi inexistente en Perú.

La Ley General de Arbitraje, aprobada mediante Decreto Legislativo 25935, eliminó la distinción entre cláusula compromisoria y convenio arbitral ${ }^{5}$. Luego, el artículo $9^{\circ}$ de la anterior Ley General de Arbitraje, aprobada mediante Decreto Legislativo $26572^{6}$ contribuyó a esta regulación y dispuso que el convenio arbitral sea el único contrato necesario para dar inicio al arbitraje. Finalmente, la actual Ley Peruana de Arbitraje,

disponía que: "Por el compromiso arbitral dos o más partes convienen que una controversia determinada, materia o no de un juicio, sea resuelta por tercero o terceros a quienes designan y a cuya jurisdicción y decisión se someten expresamente."

4 Ver: Liendo, Fernando y Reggiardo, Mario, "Aproximaciones a la litigiosidad en el Perú". En: Themis - Revista de Derecho, No. 62, 2012.

5 La Primera Disposición Final establecía que: "Toda referencia legal o contractual a cláusula compromisoria o compromiso arbitral se entiende hecha a convenio arbitral." Artículo 9.- Definición de convenio arbitral.- El convenio arbitral es el acuerdo por el que las partes deciden someter a arbitraje las controversias que hayan surgido o puedan surgir entre ellas respecto de una determinada relación jurídica contractual o no contractual, sean o no materia de un proceso judicial. El convenio arbitral obliga a las partes y a sus sucesores a la realización de cuantos actos sean necesarios para que el arbitraje se desarrolle, pueda tener plenitud de efectos y sea cumplido el laudo arbitral (...) 
aprobada mediante Decreto Legislativo 1071, siguiendo la Ley Modelo Uncitral, estableció que el pacto contenido en el convenio arbitral es autoejecutable. Así, hoy en día, la parte interesada en someter sus controversias al Tribunal Arbitral no está sujeta a la voluntad de la otra parte para dar inicio al arbitraje.

\subsection{Excepción de convenio arbitral}

La excepción de convenio arbitral es una defensa procesal que una parte puede interponer después de haber sido emplazada judicialmente con una demanda. Regulada en el artículo 16 del Decreto Legislativo $1071^{7}$, esta excepción tiene como finalidad que, en aplicación de la cláusula de convenio arbitral, el Poder Judicial rechace la demanda sin pronunciarse sobre el fondo de la controversia. Desde una perspectiva procesal, se considera que esta excepción denuncia un vicio en la relación jurídica procesal, específicamente en el interés para obrar del demandante.

\subsection{Principio de Kompetenz-Kompetenz}

El artículo 41.1 del Decreto Legislativo $1071^{8}$ recoge el principio de kompetenzkompetenz y dispone que los árbitros puedan decidir cualquier cuestionamiento relacionado con su propia competencia. Esto significa que si la parte demandada alega por ejemplo que el convenio arbitral es nulo, este cuestionamiento deberá ser resuelto por los propios árbitros cuya competencia se deriva de tal convenio arbitral ${ }^{9}$.

$7 \quad$ "Artículo $16^{\circ}$.- Excepción de convenio arbitral.-

1. Si se interpone una demanda judicial respecto de una materia sometida a arbitraje, esta circunstancia podrá ser invocada como excepción de convenio arbitral aun cuando no se hubiera iniciado el arbitraje.

2. La excepción se plantea dentro del plazo previsto en cada vía procesal, acreditando la existencia del convenio arbitral y, de ser el caso, el inicio del arbitraje.

3. La excepción de convenio arbitral, sea que se formule antes o después de iniciado el arbitraje, será amparada por el solo mérito de la existencia del convenio arbitral, salvo en el primer caso, cuando el convenio fuese manifiestamente nulo. (...)"

8 "Artículo $41^{\circ}$.- Competencia para decidir la competencia del tribunal arbitral.-1. El tribunal arbitral es el único competente para decidir sobre su propia competencia, incluso sobre las excepciones u objeciones al arbitraje relativas a la inexistencia, nulidad, anulabilidad, invalidez o ineficacia del convenio arbitral o por no estar pactado el arbitraje para resolver la materia controvertida o cualesquiera otras cuya estimación impida entrar en el fondo de la controversia. Se encuentran comprendidas en este ámbito las excepciones por prescripción, caducidad, cosa juzgada y cualquier otra que tenga por objeto impedir la continuación de las actuaciones arbitrales."

$9 \quad$ Al respecto, Rubio, Roger afirma: "El principio de Competence-Competence consiste en la posibilidad que tienen los árbitros de pronunciarse sobre su propia competencia frente a excepciones de las partes referidas a la existencia, validez o alcances del convenio arbitral. Esto se conoce como el efecto positivo del principio. El efecto negativo del principio, a su vez, permite que los tribunales judiciales limiten su revisión a una determinación prima facie de la existencia y validez del convenio arbitral para que los 
Este principio es una consecuencia de la inevitabilidad del arbitraje. En el ejemplo de la parte demandada que alega la nulidad del convenio arbitral, los jueces del Poder Judicial resolverían dicha nulidad si el principio kompetenz-kompetenz no estuviese regulado. El proceso judicial podría tardar varios años hasta obtener una sentencia firme y mientras tanto el arbitraje estaría paralizado. Cuando este principio dispone que los árbitros son competentes para resolver la nulidad del convenio arbitral, no solo se protege el acuerdo inicial de las partes por arbitrar todas las controversias regidas por el convenio, sino que ello permite que la solución del conflicto de fondo sea más rápida al evitarse un largo proceso judicial solo referido a la nulidad del convenido arbitral.

Este principio recogido en el Decreto Legislativo 1071 no implica que la decisión de los árbitros respecto a su competencia sea incuestionable. Como comentaré más adelante, la misma norma ha dispuesto un medio impugnatorio ex post para que las partes puedan cuestionar si la actuación de los árbitros se ajustó o no a las reglas establecidas en el convenio arbitral.

\subsection{Principio de separabilidad del convenio arbitral}

El artículo 41.2 del Decreto Legislativo $1071^{10}$ regula la separabilidad del convenio arbitral del contrato que lo contiene, de modo que dicho convenio no será afectado por la suerte del contrato principal así éste sea luego declarado nulo, anulable o cualquier otra forma de ineficacia o invalidez.

La autonomía del convenio arbitral es otra manifestación del principio de inevitabilidad del arbitraje, pues a pesar de que el contrato principal sea dejado sin efectos, ello no implica inmediatamente que el convenio arbitral también quede igual ${ }^{11}$. El convenio

árbitros sean los primeros en examinar su competencia y luego los tribunales judiciales ejerzan un control con la anulación o ejecución del laudo." Rubio, Roger, Comentarios a la Ley Peruana de Arbitraje, Instituto Peruano de Arbitraje Comercial y Arbitraje de Inversiones - IPA, Lima, 2011, p.471.

"Artículo $41^{\circ}$.- Competencia para decidir la competencia del tribunal arbitral.

(...)

2. El convenio arbitral que forme parte de un contrato se considerará como un acuerdo independiente de las demás estipulaciones del mismo. La inexistencia, nulidad, anulabilidad, invalidez o ineficacia de un contrato que contenga un convenio arbitral, no implica necesariamente la inexistencia, nulidad, anulabilidad, invalidez o ineficacia de éste. En consecuencia, el tribunal arbitral podrá decidir sobre la controversia sometida a su conocimiento, la que podrá versar, incluso, sobre la inexistencia, nulidad, anulabilidad, invalidez o ineficacia del contrato que contiene un convenio arbitral."

11 Cantuarias al respecto señala que "La principal explicación detrás de la existencia de esta ficción legal es que si el convenio arbitral no es considerado separado o autónomo al contrato principal que lo contiene, bastaría atacar la validez del contrato principal ante el Poder Judicial para que las partes tuvieran que esperar el fallo definitivo sobre la validez del contrato principal ( $y$ accesoriamente del pacto arbitral) para poder iniciar o proseguir 
arbitral solamente será nulo cuando no se cumplan los requisitos de validez esenciales establecidos en el artículo 13 de la Decreto Legislativo $1071^{12}$; esto es: i) acuerdo de voluntades, ii) respecto de una determinada relación jurídica; y, iii) debe constar por escrito. Por lo tanto, siempre que se cumplan con los elementos esenciales del convenio arbitral, sin importar los eventos que afecten al contrato principal, la parte interesada en dar inicio al arbitraje podrá hacerlo sin problema. Al igual que en el principio del kompetenz-kompetenz, la separabilidad del convenio arbitral no solo protege el acuerdo inicial de las partes por arbitrar sus controversias, sino que también permite que la solución del conflicto de fondo -en este caso la validez del mismo contrato- sea más rápida al evitarse el proceso judicial.

\subsection{Designación residual de árbitros}

El artículo 22.5 de la Decreto Legislativo $1071^{13}$ señala que si una de las partes se niega a nombrar su árbitro o si los árbitros no se ponen de acuerdo para designar al

el arbitraje. Es pues gracias a esta ficción legal que cualquier controversia referida a la inexistencia, ineficacia, invalidez u otro vicio del contrato que contiene el convenio arbitral, deberá, en principio, ser de conocimiento del tribunal arbitral". Cantuarias, Fernando, "Marco legal aplicable al arbitraje en el Perú: Ley General de Arbitraje y Legislación aplicable al Estado peruano". En: El Arbitraje en el Perú y en el mundo, Magna, Lima, 2008, p. 43.

12 "Artículo $13^{\circ}$.- Contenido y forma del convenio arbitral.-

1. El convenio arbitral es un acuerdo por el que las partes deciden someter a arbitraje todas las controversias o ciertas controversias que hayan surgido o puedan surgir entre ellas respecto de una determinada relación jurídica contractual o de otra naturaleza.

2. El convenio arbitral deberá constar por escrito. Podrá adoptar la forma de una cláusula incluida en un contrato o la forma de un acuerdo independiente.

3. Se entenderá que el convenio arbitral es escrito cuando quede constancia de su contenido en cualquier forma, ya sea que el acuerdo de arbitraje o contrato se haya concertado mediante la ejecución de ciertos actos o por cualquier otro medio.

4. Se entenderá que el convenio arbitral consta por escrito cuando se cursa una comunicación electrónica y la información en ella consignada es accesible para su ulterior consulta. Por "comunicación electrónica" se entenderá toda comunicación que las partes hagan por medio de mensajes de datos. Por "mensaje de datos" se entenderá la información generada, enviada, recibida o archivada por medios electrónicos, magnéticos, ópticos o similares, como pudieran ser, entre otros, el intercambio electrónico de datos, el correo electrónico, el telegrama, el télex o el telefax.

5. Se entenderá además que el convenio arbitral es escrito cuando esté consignado en un intercambio de escritos de demanda y contestación en los que la existencia de un acuerdo sea afirmada por una parte, sin ser negada por la otra." "Artículo 220.- Nombramiento de los árbitros.

(...)

5. Si una parte no cumple con nombrar al árbitro que le corresponde en el plazo establecido por las partes o, en su defecto en este Decreto Legislativo, podrá recurrirse a la institución arbitral o al tercero designado por las partes para estos efectos o, en su defecto, procederse según lo dispuesto por el artículo 230." 
presidente del Tribunal Arbitral, la designación residual no estará a cargo del Poder Judicial sino de la cámara de comercio del lugar del arbitraje. Esta norma protege la inevitabilidad del arbitraje porque al no permitir que los jueces sean los llamados a designar a los árbitros, se está respetando la voluntad de las partes de la no intromisión del Poder Judicial en ningún aspecto relacionado con el arbitraje.

Las partes podrían realmente querer ir al arbitraje, pero es comprensible que puedan no ponerse de acuerdo en nombrar al árbitro único, por ejemplo. Si fuese el Poder Judicial quien debe nombrar a ese árbitro, irían a un proceso judicial que han querido evitar justamente al pactar el convenio arbitral. El nombramiento del árbitro por una institución más expeditiva y de prestigio, como una cámara de comercio, no solo protege ese acuerdo, sino que debería ser una solución más rápida al nombramiento del árbitro.

\subsection{Limitación del recurso de anulación}

El recurso de anulación de laudo arbitral es un mecanismo de control del ejercicio de las facultades de los árbitros. En el Perú, a mi juicio, el recurso de anulación, a pesar de tener muchos elementos de propios en realidad de un proceso impugnatorio autónomo, ha sido regulado en la práctica como un aparente medio impugnatorio extraordinario $^{14}$ que sólo puede interponerse luego de haber concluido el arbitraje, limitado a una relación taxativa de causales establecidas por $l e y^{15}$ y referidas

14 Sobre el particular, Arrarte señala: "El punto más álgido y complejo surge a propósito del recurso de anulación que - a diferencia de lo que ocurre con la apelación - , solo puede ser interpuesto de manera excepcional y extraordinaria, en la medida que el vicio que contenga el laudo arbitral, esté previsto de manera expresa y taxativa como causal de anulación, es decir, un laudo solo podrá ser anulado por motivos legalmente previstos". Arrarte, Ana María, "Apuntes sobre el debido proceso en el arbitraje: la anulación del laudo y el proceso de amparo". En: Ius et veritas, No. 35, p.74 "Artículo $63^{\circ}$.- Causales de anulación.-

1) El laudo sólo podrá ser anulado cuando la parte que solicita la anulación alegue y pruebe:

a. Que el convenio arbitral es inexistente, nulo, anulable, inválido o ineficaz.

b. Que una de las partes no ha sido debidamente notificada del nombramiento de un árbitro o de las actuaciones arbitrales, o no ha podido por cualquier otra razón, hacer valer sus derechos.

c. Que la composición del tribunal arbitral o las actuaciones arbitrales no se han ajustado al acuerdo entre las partes o al reglamento arbitral aplicable, salvo que dicho acuerdo o disposición estuvieran en conflicto con una disposición de este Decreto Legislativo de la que las partes no pudieran apartarse, o en defecto de dicho acuerdo o reglamento, que no se han ajustado a lo establecido en este Decreto Legislativo.

d. Que el tribunal arbitral ha resuelto sobre materias no sometidas a su decisión.

e. Que el tribunal arbitral ha resuelto sobre materias que, de acuerdo a ley, son manifiestamente no susceptibles de arbitraje, tratándose de un arbitraje nacional. 
exclusivamente a aspectos formales del arbitraje. En principio, cualquier otro cuestionamiento judicial relacionado al fondo de la decisión contenida en el laudo no es admisible en Perú.

La limitación del recurso de anulación, de modo que no puede cuestionarse el fondo de lo resuelto por los árbitros -salvo muy reducidas excepciones bajo criterios constitucionales- promueve la efectividad material del laudo y reduce mucho las posibilidades de intervención del Poder Judicial, limitando su actuación casi únicamente a la revisión de aspectos formales. Luego analizaré esas excepciones.

\subsection{Subsanación del laudo arbitral}

Además de las expresiones del principio de inevitabilidad del arbitraje señaladas anteriormente por Bullard, considero que el artículo 63.7 del Decreto Legislativo $1071^{16}$ contiene otra expresión de este principio en el Perú: el recurso de anulación de laudo arbitral no es procedente si el vicio en la causal que se invoca pudo haber sido subsanado al interior del mismo arbitraje y la parte interesada solicitó dicha subsanación.

Después de haber emitido el laudo, la parte interesada podrá solicitar: i) rectificación en caso exista un error en el cálculo, de transcripción o tipográfico, ii) interpretación en caso exista un extremo oscuro, impreciso o dudoso, iii) integración en caso los árbitros hayan omitido resolver un extremo de la controversia y/o iv) exclusión cuando los árbitros resolvieron un extremo que no estaba sometido a arbitraje. La rectificación, interpretación, integración y/o exclusión formará parte del laudo.

La subsanación del laudo protege la inevitabilidad del arbitraje porque limita la procedencia del recurso de anulación de laudo, de modo que el vicio por el cual se pretende ir al Poder Judicial podría ser corregido por los propios árbitros. De este modo las partes ahorran tiempo y dinero en la solución final del conflicto, evitando ir al Poder Judicial. Del mismo modo, este requisito incentiva que las partes interesadas sean diligentes y usen estos mecanismos al interior del arbitraje, con lo cual se evita la intervención judicial. Por ello en caso la parte interesada encuentre que el laudo

f. Que según las leyes de la República, el objeto de la controversia no es susceptible de arbitraje $o$ el laudo es contrario al orden público internacional, tratándose de un arbitraje internacional.

g. Que la controversia ha sido decidida fuera del plazo pactado por las partes, previsto en el reglamento arbitral aplicable o establecido por el tribunal arbitral."

"Artículo 63.- Causales de anulación.

(...)

7. No procede la anulación del laudo si la causal que se invoca ha podido ser subsanada mediante rectificación, interpretación, integración o exclusión del laudo y la parte interesada no cumplió con solicitarlos." 
arbitral adolece de un error subsanable y no solicitó que los árbitros corrijan dicho error, el recurso de anulación denunciando tales vicios será improcedente.

\section{II. ¿Contra qué actos se interpone el recurso de anulación?}

El artículo 62 del Decreto Legislativo 1071 establece que el recurso de anulación se interpone contra el laudo. Si bien es cierto que no existe una definición aceptada de modo unánime, el laudo arbitral es la decisión tomada por los árbitros que, de manera definitiva y motivada, pone fin a una cuestión litigiosa que las partes le han sometido, relacionada con el fondo del asunto. Esta decisión de los árbitros puede estar contenida en un laudo parcial o en un laudo final. Será un laudo parcial cuando se resuelve de manera definitiva parte de la controversia, dejando pendiente resolver el resto del conflicto $^{17}$ al final del arbitraje; mientras que será laudo final cuando se resuelvan todos los puntos sometidos a arbitraje o aquellos que hubiese quedado pendientes y que además implica el fin del trabajo solicitado a los árbitros.

¿El recurso de anulación procede sólo cuando es dirigido contra el laudo final o también cuando lo es solo contra el laudo parcial mientras continúa el arbitraje? Veamos cuáles serían los efectos en cada uno de los supuestos. Imaginemos que una de las partes cuestiona la competencia de los árbitros y éstos desestiman dicha objeción declarándose competentes para conocer la controversia. En caso se admita el recurso de anulación contra laudos parciales, tendríamos dos procesos paralelos: el arbitraje en el que se discute el fondo de la controversia sometida a arbitraje y el proceso judicial en el que se discute la competencia de los árbitros respecto de la controversia que se sigue en el arbitraje. La consecuencia práctica es precisamente aquella que se quería evitar: la participación en paralelo del Poder Judicial.

Sin embargo, en caso sea improcedente el recurso de anulación contra laudos parciales, tendríamos un solo proceso: el arbitral. Así, habiéndose declarado competentes para conocer el fondo de la controversia, los árbitros resolverán sobre todos los puntos controvertidos restantes y recién después de haber sido emitido el laudo final, la parte interesada debería cuestionar las decisiones de los árbitros

$17 \quad$ El artículo 41 del Decreto Legislativo 1071 establece que el Tribunal Arbitral podrá decidir sobre las excepciones y objeciones a su competencia junto con la decisión de fondo o como cuestión previa mediante la emisión de un laudo parcial. En caso el Tribunal Arbitral ampare la excepción de competencia como cuestión previa y se declare incompetente, esta decisión podrá ser impugnada vía recurso de anulación. En caso el Tribunal Arbitral desestime las excepciones y objeciones, esta decisión sólo podrá ser impugnada mediante recurso de anulación contra el laudo final.

Además, si una excepción es amparada como cuestión previa respecto de determinadas materias, el arbitraje continuará respecto de las demás materias y esta decisión sólo podrá ser impugnada vía recurso de anulación luego de emitirse el laudo definitivo. De la misma manera, la resolución que desestima la recusación de uno de los árbitros sólo podrá ser impugnada vía recurso de anulación contra el laudo. 
mediante el recurso de anulación de laudo. Sólo en ese momento, el Poder Judicial será competente para revisar ambos laudos. A mi juicio, si partimos de la premisa que la celebración del convenio arbitral es una declaración expresa de las partes de no participación del Poder Judicial, el recurso de anulación debería interponerse solo contra el laudo final, ya que de esa manera no solo las partes sino el mismo Poder Judicial consumen menos recursos en revisar los vicios del arbitraje, ya que evitará la duplicidad de muchos actos procesales sucesivos.

Esta interpretación además va en la línea de lo dispuesto por el artículo 41.5 del Decreto Legislativo 1071, cuando señala que si los árbitros desestiman una excepción u objeción como cuestión previa, la decisión solo podrá ser impugnada mediante recurso de anulación contra el laudo final.

Sin embargo, esta posición tiene un riesgo y es que en caso de arbitrajes fraudulentos o cuando el arbitraje es muy largo, una de las partes podría verse afectada de modo irreparable con la ejecución del laudo parcial, sin que dicha parte tenga la posibilidad de cuestionar dicho laudo parcial vía el recurso de anulación. En esos casos fraudulentos sí debería admitirse el recurso, dado que el costo de la afectación al afectado sería mayor que los beneficios obtenidos con el ahorro de esperar al cuestionamiento del laudo final.

\section{III. ¿Proceso o medio impugnatorio?}

No existe consenso respecto a la llamada "naturaleza jurídica" del recurso de anulación de laudo ${ }^{\mathbf{1 8}}$. Algunos sostienen que se trata de un una pretensión impugnatoria que genera un proceso autónomo ${ }^{19}$ como lo serían la nulidad de cosa juzgada fraudulenta o el amparo contra resolución judicial, mientras que otros afirman que se trata de un medio impugnatorio ${ }^{20}$. Bullard plantea una visión menos doctrinaria y más pragmática sobre este asunto:

18 Alva Navarro, Esteban sostiene que: "El asunto no es sencillo. La discusión de si el recurso de anulación constituye en realidad una pretensión impugnativa - semejante a los distintos recursos regulados en cada procedimiento para cuestionar las decisiones dictadas en ellos - o más bien una pretensión autónoma de nulidad - capaz de iniciar un nuevo proceso con el propósito de obtener una sentencia declarativa de la invalidez del pronunciamiento de los árbitros, a modo de la pretensión de nulidad de cosa juzgada fraudulenta - ha motivado ya muchas líneas dentro de la doctrina arbitral; e incluso ha ido más allá, pasando a ser parte de la agenda modificatoria de importantes legislaciones arbitrales en el mundo." Alva Navarro, Esteban, La anulación del Laudo, Palestra Editores, Lima, 2011, p. 47.

19 Para Verger, se trata de una acción autónoma que se resuelve por la jurisdicción ordinaria civil en una única instancia. Verger Grau, Joan, "¿Se puede impugnar el laudo arbitral español? "En: Revista Peruana de Derecho Procesal, 1998, p.269. impugnación, como el que admite un auténtico recurso que permita a los órganos 


\begin{abstract}
"Usualmente se considera que el recurso de anulación sirve para proteger garantías procesales. Esa visión encaja en la idea de que el convenio arbitral es contractual, pero la tramitación del arbitraje es procesal. De cierta manera, bajo esa visión, el arbitraje nace en el Derecho privado derecho contractual- pero termina como Derecho Público - derecho procesal -. Y ello sería lo que justificaría su revisión por el órgano jurisdiccional a fin de preservar aspectos similares a los que se protege con una nulidad procesal ante jueces ordinarios.

Creemos que esa visión es equivocada. La posición que consideramos correcta radica en que el recurso de anulación es la forma de proteger y ejecutar el convenio arbitral. Es la forma como se garantiza que la existencia y los términos del acuerdo para arbitrar sean respetados. La anulación es consecuencia de que el carácter autoejecutable del convenio excluye la revisión previa a la ejecución, pero necesita un mecanismo posterior de revisión si la ejecución no fue adecuada por ir contra la ley o contra el pacto." ${ }^{21}$
\end{abstract}

Coincido con Bullard en que el recurso de anulación es un mecanismo que permite controlar que los árbitros respeten el convenio arbitral y que lo pactado en éste respete la ley. Por ello el Poder Judicial sólo debería poder pronunciarse sobre aspectos formales que en el peor de los casos le quiten validez al laudo, pero en ningún caso debe resolver el tema de fondo discutido en el arbitraje. Esta prohibición está contenida en el artículo 62.2 del Decreto Legislativo 1071 que dispone que no cabe la revisión del fondo de la controversia, a pesar que se haya incurrido en algún error de interpretación de la norma aplicable o de la valoración de los hechos y las pruebas. El Tribunal Constitucional, no obstante, abriría luego algunas puertas para ello.

Más allá de consideraciones dogmáticas sobre si el recurso de anulación es un medio impugnatorio o un proceso impugnatorio, evaluaré qué es lo que tenemos regulado en el Perú y sugeriré cómo aplicarlo para que su aplicación genere antes que nada un beneficio social.

jurisdiccionales un nuevo conocimiento del asunto como si se tratase de una segunda instancia; el que admite la anulación del laudo únicamente por determinados motivos, establecidos legalmente; el que admite la impugnación a través de un incidente de oposición en la fase de ejecución del laudo; y por último, el que admite el cuestionamiento a través de la pretensión autónoma nula. Frente a estos sistemas, la derogada Ley General de Arbitraje acogía el primer y segundo sistema de impugnación, de tal manera que los laudos podían ser cuestionados a través del recurso de apelación y anulación. El actual Decreto Legislativo 1071 solo acoge el recurso de anulación como medio impugnatorio, postlaudo; es la única vía de impugnación del laudo, pues todo laudo es inapelable y de obligatorio cumplimiento desde su notificación a las partes." Ledesma Narváez, Marianella, Jurisdicción y Arbitraje, Fondo Editorial PUCP, 2da ed., Lima, 2010, p.144.

21 Bullard G., Alfredo, "¿Qué fue primero: el huevo o la gallina? El Carácter contractual del recurso de anulación". En: Revista Internacional de Arbitraje, Julio - Diciembre 2013, Lima, p. 76. 
El artículo 64 del Decreto Legislativo $1071^{22}$ nos da una idea acerca del tratamiento que el legislador le ha dado a esta institución. Una primera lectura de los incisos 1, 2, 3 y 4 de la referida norma da a entender inicialmente que nos encontramos ante un proceso judicial autónomo ${ }^{23}$ porque:

22 "Artículo 64.- Trámite del recurso.-

1. El recurso de anulación se interpone ante la Corte Superior competente dentro de los veinte (20) días siguientes a la notificación del laudo. Cuando se hubiere solicitado la rectificación, interpretación, integración o exclusión del laudo o se hubiese efectuado por iniciativa del tribunal arbitral, el recurso de anulación deberá interponerse dentro de los veinte (20) días de notificada la última decisión sobre estas cuestiones o de transcurrido el plazo para resolverlos, sin que el tribunal arbitral se haya pronunciado.

2. El recurso de anulación debe contener la indicación precisa de la causal o de las causales de anulación debidamente fundamentadas y acreditadas con los medios probatorios correspondientes. Sólo pueden ofrecerse documentos. Las partes podrán presentar las copias pertinentes de las actuaciones arbitrales que tengan en su poder. Excepcionalmente y por motivos atendibles, las partes o la Corte podrán solicitar que el tribunal arbitral remita las copias pertinentes de dichas actuaciones, no siendo necesario el envío de la documentación original. Asimismo el recurso de anulación debe contener cualquier otro requisito que haya sido pactado por las partes para garantizar el cumplimiento del laudo.

3. La Corte Superior competente resolverá de plano sobre la admisión a trámite del recurso dentro de los diez (10) días siguientes, excepto en el caso previsto en el numeral 4 del artículo $66^{\circ}$ en el que previamente deberá cumplirse con el trámite que en él se establece. Una vez admitido a trámite el recurso de anulación, se dará traslado a la otra parte por el plazo de veinte (20) días para que exponga lo que estime conveniente y ofrezca los medios probatorios correspondientes. Sólo pueden ofrecerse documentos.

4. Vencido el plazo para absolver el traslado, se señalará fecha para la vista de la causa dentro de los veinte (20) días siguientes. En la vista de la causa, la Corte Superior competente podrá suspender las actuaciones judiciales por un plazo no mayor a seis (6) meses a fin de dar al tribunal arbitral la oportunidad de reanudar las actuaciones arbitrales o de adoptar cualquier otra medida que, a criterio de los árbitros elimine las causales alegadas para el recurso de anulación. En caso contrario, resolverá dentro de los veinte (20) días siguientes.

5. Contra lo resuelto por la Corte Superior sólo procede recurso de casación ante la Sala Civil de la Corte Suprema, cuando el laudo hubiera sido anulado en forma total o parcial." Respecto a la definición de proceso civil, Liebman sostiene que: "La actividad mediante la cual se desarrolla en concreto la función jurisdiccional se llama proceso. Dicha función no se cumple, en efecto, en un solo tiempo o con un solo acto, sino con una serie coordinada de actos que se desarrollan en el tiempo y que tienden a la formación de un acto final (...) En su conjunto, el contenido de esta actividad diversa se ordena en el esquema de una demanda que una parte dirige al órgano jurisdiccional frente a la contraparte, y a la cual el órgano responde con su providencia; entre estos dos actos, uno que abre y el otro que cierra el proceso se desarrolla una actividad intermedia más o menos compleja, dirigida a preparar y hacer posible precisamente el pronunciamiento del acto final, actividad que se cumple en el contradictorio efectivo o al menos virtual de la contraparte." LIEBMAN, Enrico, Manual del derecho procesal civil, Colección Ciencia del proceso, Europa-América, Vol. 68, 1980. p.25. 
- Se trata de una pretensión impugnatoria que inicia un proceso nuevo y autónomo, destinado a verificar que los árbitros hayan respetado el convenio arbitral y la ley que regula sus actuaciones.

- El recurso de anulación debe tener una debida fundamentación y los medios probatorios documentales correspondientes, lo cual lo asemeja a una demanda. Además, la práctica judicial ha llevado a que se le dé la forma de una demanda, entendida como el escrito que da inicio a un proceso civil o comercial ${ }^{24}$.

- Una vez admitido a trámite el recurso de anulación, la Corte Superior corre traslado a la otra parte para que exponga lo que estime pertinente y ofrezca medios probatorios correspondientes. El escrito en el que la contraparte absuelve el traslado, viene siendo presentado como una contestación de demanda en la que el emplazado expone los fundamentos de hecho y de derecho de su posición, así como ofrece medios de prueba sobre su posición ${ }^{25}$.

Mediante resolución del 9 de diciembre de 1999, la Sala Civil declaró improcedente el recurso de anulación de laudo por indebida acumulación de pretensiones, señalando que de acuerdo a la Primera Disposición Complementaria y Final del Código Civil las disposiciones de dicho cuerpo normativo se aplican supletoriamente a los demás ordenamientos procesales siempre que sean compatibles con su naturaleza: "Tercero.Que, la Ley General de Arbitraje en su artículo sesentiuno señala que contra el laudo arbitral solamente procede la interposición del recurso de anulación ante el Poder Judicial por las causales taxativamente establecidas en el artículo setentitrés de dicha ley arbitral. Cuarto.- Que, la Primera Disposición Complementaria y Final del Código Procesal Civil señala que, las disposiciones de este Código se aplican supletoriamente a los demás ordenamientos procesales, siempre que sean compatibles con su naturaleza. Quinto.Que, el artículo ochentitrés del Código Procesal Civil precisa que cuando en un proceso hay más de una pretensión planteada en la demanda, es una acumulación objetiva originaria; indicando por su parte el artículo ochenticinco del mismo Código que se pueden acumular pretensiones en un proceso siempre y cuando éstas sean de competencia del mismo juez, no sean contrarias entre sí, salvo que se propongan en forma subordinada o alternativa, y que sean tramitables en una misma vía procedimental (sic)".

25 Así, en la sentencia recaída en el expediente 165-2011, la $5^{\circ}$ Sala Comercial señala cuál fue el trámite del recurso de anulación de laudo: "resulta que (...) la Procuradora Pública a cargo de los asuntos judiciales del Poder Judicial, interpone demanda de anulación de laudo arbitral dictado en el proceso arbitral iniciado por la empresa AAA Sociedad Anónima Cerrada; manifiesta que el Tribunal Arbitral compuesto por los árbitros XX, YY y $\mathrm{ZZ}$, al laudar declarando fundada en parte la demanda de resolución de contrato, por incumplimiento del Poder Judicial; y, la indemnización por daños y perjuicios, han incurrido en causales de anulación, esto es, primero la incompetencia de uno de los árbitros; segundo, la materia sometida a la decisión arbitral no puede ser manifiestamente objeto de arbitraje; y, por último, el laudo se ha expedido fuera del plazo; ampara su pedido en el artículo 73, incisos 1), 7) y 5) de la Ley 26572, respectivamente; que, por resolución número tres, de veintiséis de diciembre del dos mil uno, corriente de fojas treinta y cuatro, al haberse remitido a este órgano jurisdiccional el respectivo expediente de laudo arbitral, se admite la presente demanda, corriéndose 
- Los actos procesales de los jueces en la tramitación del recurso tienen naturaleza jurisdiccional, de modo que la actuación de los jueces y los derechos y deberes de las partes -salvo lo expresamente regulado en el Decreto Legislativo 1071- se rigen por la Constitución Política, la Ley Orgánica del Poder Judicial y el Código Procesal Civil.

El Tribunal Constitucional ha contribuido a reforzar esta posición:

"Que se haya previsto por mandato del Decreto Legislativo No 1071, que norma el Arbitraje, la posibilidad de un recurso de anulación (como en la derogada Ley General de Arbitraje se establecieron los recursos de apelación y de anulación) como fórmula a posteriori, no significa que tal mecanismo sea parte integrante del proceso arbitral. Se trata más bien, por su propia finalidad así como por la configuración judicial de la que se encuentra dotado, de una verdadera opción procesal cuyo propósito, técnicamente hablando, puede sustituir al amparo cuando de la defensa de derechos constitucionales se trate..$^{126}$

Reconozco que más allá que el Decreto Legislativo 1071 utilice el término "recurso", lo cual es un tipo de medio impugnatorio, la regulación y la práctica judicial hacen que la anulación de laudo funcione como un proceso judicial autónomo. Pero existen dos situaciones que hacen que estemos entonces ante un proceso judicial que vulnera el derecho de defensa (o que tal vez nos lleven a repensar que es mejor que lo volvamos a considerar como un medio impugnatorio para efectos prácticos):

- Pluralidad de instancia: El artículo 64.5 de la Decreto Legislativo 1071 establece que si el laudo es anulado de forma total o parcial, contra lo resuelto por la Corte Superior sólo procede recurso de casación, el cual será resuelto por la Sala Civil de la Corte Suprema. Si el llamado recurso de anulación es un proceso autónomo, la regla contenida en el artículo 64.5 del Decreto Legislativo 1071, al permitir que sólo el demandado tenga la posibilidad de interponer recurso de casación, vulneraría el derecho constitucional del demandante a la pluralidad de instancia.

El artículo 139.6 de la Constitución Política del Perú ${ }^{27}$ recoge el derecho a la pluralidad de instancia, el cual permite al justiciable solicitar que se revise una

traslado de la misma a la parte demandada; que, por escrito de fojas setentiuno a fojas setenta y siete, la empresa demandada AAA S.A.C., absuelve el traslado, exponiendo lo conveniente a su derecho según los fundamentos en él contenidos; que, de fojas ochenta y ocho a fojas noventa y dos corre el dictamen fiscal; que, por resolución de veintiuno de mayo del dos mil dos, corriente de fojas noventa y tres, se señaló fecha para la vista de la causa; y, habiéndose realizado ésta, ha llegado el momento de expedir sentencia (sic)".

26 STC 00142-2011-PA/TC.

27 "Artículo 139.- Son principios y derechos de la función jurisdiccional: 
resolución judicial alegando que los magistrados podrían haber cometido un error. De esta manera se garantiza que el interesado pueda solicitar la revisión de la actuación y decisión de los jueces y/o tribunales ante el superior jerárquico dentro del mismo organismo que sirve justicia. Se supone que el fundamento de la doble instancia es que el superior jerárquico está dotado de mayor conocimiento jurídico y experiencia, lo que asegura una mejor calidad en la resolución y minimiza la probabilidad de error. Pero ello no necesariamente es el fundamento de la pluralidad de instancia, porque existen procesos donde una sala de la Corte Suprema funciona como primera instancia y otra sala de la misma Corte Suprema luego como segunda instancia. Ello me lleva a pensar que no se trata de una cuestión de jerarquía, sino simplemente de que alguien pueda revisar el eventual error cometido en un inicio, limitándose la discusión de segunda instancia (el grado) a lo que se alegó como vicio. Al respecto, García Toma señala:

"En puridad, se trata del ejercicio del derecho al recurso impugnatorio. Así, lo que resulta cautelado es que las decisiones de los jueces y tribunales, una vez terminada una etapa del proceso, pueden ser objeto de una ulterior revisión que tome en cuenta su desarrollo y la decisión adoptada.

El derecho al recurso impugnatorio que subyace en el principio de la pluralidad de la instancia, permite exponer ante el superior jerárquico la observación de un error in iudicando o in procedendo."128

El arbitraje en rigurosidad ${ }^{29}$ es un mecanismo de ejecución contractual, por el cual las partes deciden que sea un tercero quien resuelva sus controversias sobre dicho contrato. En algunos países, como en el Perú, la Constitución Política le otorga además a las actuaciones de estos árbitros, el efecto de un acto jurisdiccional, de modo que el laudo tiene vocación de resolver de modo definitivo la controversia entre las partes. Pero el que se le otorgue los efectos jurisdiccionales no implica automáticamente que el arbitraje esté sujeto a los principios que rigen los procesos judiciales. Por ello muchos principios de la Constitución referidos al Poder Judicial y muchas normas de los códigos procesales pueden llegar a ser incompatibles con el arbitraje. Ello, por cierto, no impide que proceso judicial y arbitraje tengan aspectos comunes que puedan compartir sin espantarse como si se tratase de dos materias completamente distintas. Es más, muchas instituciones procesales deberían ser estudiadas en el arbitraje, incluso eventualmente para descartarlas pero con conocimiento de causa, sin la soberbia de algunos defensores del arbitraje que parten de cero como si el proceso no tuviese siglos de investigación que lo

\section{(...)}

6. La pluralidad de la instancia."

28 García Toma, Víctor, Los derechos fundamentales, Editorial Adrus, 2da. Ed, Lima, 2013, p. 1102.

29 No estoy considerando en esta definición a los arbitrajes obligatorios dispuestos excepcionalmente en algunas normas legales. 
respalden. Por ejemplo, en relación al derecho de defensa, Bustamante señala lo siguiente:

'Como regla general, podemos decir que, si bien el debido proceso resulta aplicable a cualquier tipo de proceso, algunos de sus elementos pueden no resultar exigibles en un determinado proceso - como es el caso del arbitraje - en la medida que razonablemente (lo que implica fin lícito y proporcionalidad) no resulten esenciales para que el debido proceso pueda cumplir con sus funciones y no pierda su naturaleza para convertirse en algo distinto. Dicho de otra manera, siempre resultarán exigibles $-y$, por ende, aplicables en cualquier tipo de proceso, incluyendo el arbitraje aquellos elementos del debido proceso que resulten razonablemente imprescindibles para que el inicio, desarrollo, conclusión y ejecución de un proceso pueda ser considerado justo (o, si se prefiere, para que los intereses jurídicos que protegen resulten real, concreta y efectivamente protegidos). De no ser así, los procesos en mención resultarían inválidos. ${ }^{\prime \prime 30}$

Coincido con Bustamante cuando señala que el principio de pluralidad de instancias no es compatible con el arbitraje. Obligar que exista una segunda instancia arbitral que revise el laudo desvirtuaría los objetivos del arbitraje. Sin embargo, si el recurso de anulación de laudo es realmente un proceso autónomo, más allá de que la pretensión de la demanda de anulación tenga como finalidad revisar si en el arbitraje se respetó lo pactado en el convenio arbitral o si lo pactado en el convenio arbitral respetó la ley, ambas partes deberían bajo ese contexto tener la posibilidad de acceder a una revisión de lo resuelto en primera instancia.

En el Perú la Corte Superior es el órgano que conoce en primera instancia la pretensión de anulación de laudo. Si la Corte declara fundada la pretensión, de acuerdo al artículo 64.5 del Decreto Legislativo 1071, el demandado podrá interponer recurso de casación para solicitar que la Corte Suprema revise la decisión de la Corte Superior. En este caso sí se respeta el derecho constitucional a la pluralidad de instancia. Sin embargo, la situación es distinta para el demandante. Si la pretensión es infundada, el demandante no podrá acceder a la Corte Suprema para que revise la resolución de primera instancia. Esta regulación vulneraría el derecho constitucional a la doble instancia del demandado $y$, eventualmente, el derecho constitucional a la igualdad ante la ley, porque el derecho a la pluralidad de instancia se concede solo a una de las partes y no a ambas ${ }^{31}$.

Bustamante Alarcón, Reynaldo, "La constitucionalización del arbitraje en el Perú; algunas consideraciones en torno a la relación del arbitraje con la Constitución, los derechos fundamentales y el Estado de derecho". En: Revista de la Facultad de Derecho PUCP, No. 71,2013, p. 404

31 En este caso, se debe entender el derecho constitucional a la igualdad de la ley como lo explica García Toma: "En ese contexto, la igualdad aparece para consolidar la seguridad jurídica, ya que obliga al sistema a generar un marco de estabilidad y certeza. Para tal 
Para salvar esta posible inconstitucionalidad de la norma, podríamos sostener que el recurso de anulación de laudo no es un proceso judicial autónomo, sino solo un medio impugnatorio extraordinario con requisitos especiales de procedencia, determinados a partir del tipo de caso en el que nos encontramos. $Y$ en el caso de la anulación de laudo, la confirmación de la validez del laudo en primera instancia por el Poder Judicial sería suficiente para terminar definitivamente el conflicto. Si es un medio impugnatorio, la Corte Superior actuaría como una segunda instancia que solo revisa una tipo de pretensión impugnatoria nulificante, donde evalúa si los árbitros respetaron el convenio arbitral o éste respeto la ley. Pero sostener esto parece un poco forzado. Si mantenemos la idea de que estamos ante un proceso autónomo, simplemente podemos considerar que al ser la finalidad de las partes resolver su conflicto rápido a través del arbitraje, sin posibilidad de revisión del fondo del laudo en una instancia adicional, también dicho proceso de anulación debe sujetarse a las mismas condiciones del arbitraje, de modo que dicho proceso judicial sea de instancia única. Podríamos incluso considerar que si las partes en el Perú pactan un convenido arbitral donde la regla general es de una sola instancia, igual sería en caso se llegue a la anulación de laudo. Esa sería incluso una regla supletoria eficiente. Pero no podemos negar que la Constitución Política dispone la pluralidad de instancia en sede judicial y esta garantía por ahora podría tener que

efecto, dicho principio-derecho, se vislumbra a través de las nociones de igualdad ante la ley e igualdad en la aplicación de la ley (...). La igualdad en la elaboración de la ley. Ello se refiere a la exigencia de contenidos normativos generales y abstractos; vale decir, preceptivamente impersonal e indeterminada en relación con sus destinatarios, así como una proposición en términos de un supuesto que apunta a un debe ser, en el que queda encuadrada cualquier citación que pudiera darse en la realidad. En ese contexto, opera como un límite a la discrecionalidad del legislador. Así, supone que este se encuentre impedido de configurar pautas preceptivas diferentes cuando no existen situaciones de hecho relevantes para ello." García Toma, Víctor, Derechos Fundamentales, Adrus, Lima, 2013, 2da.Ed. pp. 174-175.

En ese mismo sentido, Rubio Correa sostiene que: "La igualdad debe plasmarse tanto en la elaboración de los textos normativos como en su aplicación. Es necesario vigilar la existencia de igualdad en los dos ámbitos indicados, y no solo en uno de ellos (...)". Rubio Correa, Marcial, La interpretación de la Constitución según el Tribunal Constitucional, Fondo Editorial PUCP, Lima, 2005, p. 160.

Además, Gutiérrez y Sosa señalan que: "Tanto la igualdad en el contenido de la ley como la igualdad en su aplicación forman parte del concepto de igualdad ante la ley, al que se refiere la Constitución (...) Así considerada, la igualdad en el contenido de la ley impone también un límite constitucional a la actuación del legislador, al no poder apartarse de este marco impuesto por el ordenamiento, para crear normas que sin más contravengan la igualdad de trato. Expresada esta garantía como derecho fundamental, implica la posibilidad de que toda persona pueda defenderse frente a normas estatales que contengan diferencias irrazonables y que afecten su situación jurídica o legítimas expectativas." Gutiérrez, Walter, et al., La Constitución Comentada, Gaceta Jurídica, Tomo I, 2da Ed., Lima, 2013, pp.103-104. 
respetarse, salvo que se interprete que no es aplicable al recurso de anulación por ser solo un medio impugnatorio extraordinario en el contexto arbitral ${ }^{32}$.

- Intervención de los árbitros en el recurso de anulación: El artículo 64 del Decreto Legislativo 1071 no regula la situación procesal de los árbitros en el proceso judicial llamado "recurso de anulación de laudo". Frente a ello hay dos escenarios. Si consideramos que el recurso de anulación inicia un proceso judicial autónomo, entonces también se debería emplazar a los árbitros como partes demandadas del proceso a fin de que ejerzan su derecho de defensa a raíz del cuestionamiento de su trabajo. En la medida que el Poder Judicial revisará si los árbitros actuaron respetando el convenio arbitral y la ley que lo regula, tendrían legitimidad para obrar pasiva. Al igual que en el proceso de nulidad de cosa juzgada fraudulenta ${ }^{33} y$ el proceso de amparo contra resoluciones judiciales ${ }^{34}$, el proceso de anulación de

32 A mi juicio, la mayoría de las discusiones sobre la naturaleza de las instituciones jurídicas me parecen estériles, pues se basan solo en consideraciones lógico-abstractas que nada aportan al beneficio social que una buena institución jurídica debe generar. En este caso, si bien es un tema discutible en el que existen argumentos suficientes para defender ambas posiciones, mi objetivo es solo determinar qué es lo más favorable para una solución eficiente y eficaz de los conflictos en el Perú.

33 "Artículo 178.- Nulidad de Cosa Juzgada Fraudulenta.- Hasta dentro de seis meses de ejecutada o de haber adquirido la calidad de cosa juzgada, si no fuere ejecutable puede demandarse, a través de un proceso de conocimiento la nulidad de una sentencia o la del acuerdo de las partes homologado por el Juez que pone fin al proceso, alegando que el proceso que se origina ha sido seguido con fraude, o colusión, afectando el derecho a un debido proceso, cometido por una, o por ambas partes, o por el Juez o por éste y aquellas.

Puede demandar la nulidad la parte o el tercero ajeno al proceso que se considere directamente agraviado por la sentencia, de acuerdo a los principios exigidos en este Título.

En este proceso sólo se pueden conceder medidas cautelares inscribibles.

Si la decisión fuese anulada, se repondrán las cosas al estado que corresponda. Sin embargo la nulidad no afectará a terceros de buena fe y a título oneroso.

Si la demanda no fuera amparada, el demandante pagará las costas y costos doblados y una multa no menor de veinte unidades de referencia procesal".

"Artículo 4.- Procedencia respecto de resoluciones judiciales.- El amparo procede respecto de resoluciones judiciales firmes dictadas con manifiesto agravio a la tutela procesal efectiva, que comprende el acceso a la justicia y el debido proceso. Es improcedente cuando el agraviado dejó consentir la resolución que dice afectarlo.

El hábeas corpus procede cuando una resolución judicial firme vulnera en forma manifiesta la libertad individual y la tutela procesal efectiva.

Se entiende por tutela procesal efectiva aquella situación jurídica de una persona en la que se respetan, de modo enunciativo, sus derechos de libre acceso al órgano jurisdiccional, a probar, de defensa, al contradictorio e igualdad sustancial en el proceso, a no ser desviado de la jurisdicción predeterminada ni sometido a procedimientos distintos de los previstos por la ley, a la obtención de una resolución fundada en derecho, a acceder a los medios impugnatorios regulados, a la imposibilidad de revivir procesos fenecidos, a la actuación adecuada y temporalmente oportuna de las resoluciones judiciales y a la observancia del principio de legalidad procesal penal." 
laudo podría involucrar a los árbitros que dictaron el laudo cuestionado. En cambio, si asumimos que el recurso de anulación de laudo es un medio impugnatorio extraordinario, entonces no existiría la necesidad de emplazar a los árbitros, porque el Poder Judicial sería solo una instancia superior que revise las resoluciones de los árbitros, al igual como lo hacen los vocales de una corte con las resoluciones de un juez especializado. $Y$ un juez de instancia inferior no defiende su resolución impugnada ante los jueces de la instancia superior.

A mi juicio, lo importante es saber si conviene o no que los árbitros sean emplazados en el llamado "recurso de anulación". Tengamos en cuenta que el costo en tiempo para los jueces de evaluar la posición de los árbitros -además de las posición de las partes del arbitraje- frente al recurso de anulación, es superior al beneficio de reducir el margen de error que se obtendría si se les permitiese ejercer a los árbitros la posibilidad de defender sus actuaciones. El beneficio de la reducción de la probabilidad de error judicial con los árbitros defendiendo su laudo, sería mínimo, pues esos argumentos de defensa los suele aportar la parte contractual también demandada en el proceso de anulación de laudo, quienes tienen mayor interés que los mismos árbitros en que se confirme el laudo. Incorporar a los árbitros como parte del "proceso de anulación" implicaría mayor tiempo invertido en leer escritos, mayor gasto en tasas judiciales, eventual gasto en honorarios de abogados defensores de los árbitros, gasto adicional en horas-hombre, papel, tinta, electricidad y demás recursos que son escasos en una sociedad pobre como la peruana. Seguir un proceso con más de dos partes es más tedioso para los operadores jurisdiccionales y para las mismas partes. Por eso es suficiente con que la parte vencedora del arbitraje defienda lo allí resuelto, sin necesidad de emplazar a los árbitros. El único beneficio que se obtendría al incorporarlos es que aporten argumentos mediante el ejercicio de su derecho de defensa. Pero este beneficio no es superior al costo de tenerlos durante el trámite del recurso de anulación. La situación sería parecida a la que se presenta en el caso de los jueces, cuando uno de primera instancia no se defiende ante los jueces de segunda instancia cuando las partes impugnan sus decisiones.

Si consideramos que el recurso de anulación de laudo es un medio impugnatorio extraordinario, no es necesario notificar al Tribunal Arbitral. Eso acelera la solución del conflicto al evitar una doble instancia y emplazar a los árbitros. Pero si lo consideramos un proceso impugnatorio, nos encontramos frente a esos inconvenientes no resueltos por la regulación del Decreto Legislativo 1071. 


\section{Causales de anulación del laudo}

El recurso de anulación de laudo no sirve para cuestionar el fondo del conflicto resuelto en el laudo. Solo cabe frente a ciertas causales sobre las que Bullard ${ }^{35}$ plantea una muy útil clasificación: i) las que buscan determinar si lo pactado y/o su ejecución fueron afines con la ley, a las que él denomina causales "tipo I", y ii) las que buscan determinar que la actuación arbitral se hizo de acuerdo a lo pactado en el convenio arbitral, a las que él denomina causales "tipo II." Por ello revisaré las causales previstas en el artículo 63 de la Decreto Legislativo 1071 y las clasificaré en tipo I o II de acuerdo a los criterios de Bullard.

\subsection{Nulidad o invalidez del convenio arbitral}

El artículo 63.1.del Decreto Legislativo 1071 señala que procede el recurso de anulación cuando el convenio arbitral es inexistente, nulo, anulable, inválido o ineficaz. Esta causal cuestiona el convenio arbitral por no respetar la ley. En caso se determine que ello ocurrió así, corresponde analizar si esta afectación genera la nulidad, inexistencia o ineficacia del convenio arbitral.

Para Ledesma se trata de una causal que se sustenta en disposiciones de derecho sustantivo porque se refiere a causas que generan la nulidad del convenio por afectar requisitos esenciales como: falta de consentimiento de acudir al arbitraje, cuando la voluntad no se deduce claramente de un intercambio de comunicaciones, cuando no se celebre por escrito e incluso cuando el consentimiento haya sido obtenido mediante falsedad, engaño, fraude, incapacidad de las partes etc. ${ }^{36}$.

La norma señala que el recurso de anulación por esta causal sólo será procedente si la parte interesada interpuso reclamo ante el Tribunal Arbitral y éste fue desestimado. Cantuarias afirma que este requisito se justifica porque el proceso de anulación es una vía tan rápida que no permitiría un análisis minucioso y profundo de la supuesta afectación al convenio arbitral ${ }^{37}$. De allí que esta causal esté vinculada con el principio de subsanación del laudo arbitral desarrollada en el primer acápite de este trabajo.

El cuestionamiento del convenio arbitral es esencial para determinar si la voluntad de las partes, al declarar la no participación del Poder Judicial en la solución de sus conflictos, estuvo afectada de algún vicio que acarree su inexistencia, nulidad o

35 Bullard G., Alfredo, "¿Qué fue primero: el huevo o la gallina? El Carácter contractual del recurso de anulación". En: Revista Internacional de Arbitraje, Julio - Diciembre 2013, Lima, p. 81.

36 Ledesma Narváez, Marianella, Jurisdicción y Arbitraje, Fondo Editorial PUCP, 2da.Ed., Lima, 2010, p.156.

37 Cantuarias Salaverry, Fernando, "Marco legal aplicable al arbitraje en el Perú: Ley General de Arbitraje y Legislación aplicable al Estado peruano". En: El Arbitraje en el Perú $y$ en el mundo, Lima: Magna, 2008, p.478. 
ineficacia. De esta manera se garantiza que la manifestación de voluntad de las partes no estuvo afectada, por ejemplo, por un vicio resultante de error, dolo, violencia o intimidación ${ }^{38}$. Esta es una causal tipo I.

\subsection{No se notificó un acto arbitral esencial o se vulneró el derecho de defensa}

De acuerdo al artículo 63.1.b del Decreto Legislativo 1071 puede interponerse recurso de anulación cuando se alega que una de las partes no ha sido debidamente notificada del nombramiento de un árbitro o de las actuaciones arbitrales, o no ha podido por cualquier otra razón, hacer valer sus derechos. Esta es una causal tipo II.

El hecho que una de las partes no haya sido debidamente notificada del nombramiento de un árbitro o de las actuaciones arbitrales es una causal válida en la medida en que el arbitraje debe tramitarse con la participación de ambas partes en un tema tan relevante como este. Por ello este aspecto de la causal no genera mayor controversia.

Esta causal también señala que procederá el recurso de anulación cuando una de las partes no haya podido hacer valer sus derechos. La norma se refiere al derecho de defensa pactado en el convenio o en el reglamento. La norma es clara al no mencionar el derecho al "debido proceso", lo que significa que, en principio, no se puede invocar cualquier manifestación del derecho al debido proceso conforme a las distintas situaciones reguladas en el Código Procesal Civil e, incluso, en la misma Constitución Política ${ }^{39}$. Landa, citado por Alva, señala que "con toda razón, se ha sostenido que

38 Respecto a la importancia de la manifestación de la voluntad de las partes para someterse al arbitraje, Alva Navarro, Esteban señala que: "A diferencia de lo que ocurre con el proceso judicial, el proceso arbitral no debería - en teoría - ser impuesto a las partes, pues su existencia y sustento principal están íntimamente ligados a la libre voluntad de los particulares. Es pacíficamente aceptado en doctrina que el arbitraje se sustenta primariamente en la autonomía privada de los sujetos quienes en uso de este atributo acuerdan renunciar a la jurisdicción natural que les proporciona el Estado - la judicial - y someterse, por voluntad propia, a un medio de administración de justicia distinto, encargado a jueces que no son los impuestos por la justicia pública, sino elegidos por ellos mismos para resolver el conflicto de intereses en el cual se ven envueltos." Alva Navarro, Esteban, La anulación de laudo, Palestra Editores S.A.C., Lima, 2011 , p. 112.

39 Arrarte señala que: "dado el carácter excepcional y taxativo de las causales de anulación, su interpretación debe ser restrictiva, por lo que no consideramos jurídicamente válido sostener que la consecuencia de anulación prevista para una manifestación específica del debido proceso, esto es, para la vulneración del derecho de defensa, pueda ser ampliada a todos los derechos que integran el primero. Por tanto, a priori, podemos llegar a la conclusión de que la causal de anulación contemplada no se refiere al debido proceso (género) sino al derecho de defensa de manera concreta." Arrarte, Ana María. "Apuntes sobre el debido proceso en el arbitraje: la anulación del laudo y el proceso de amparo", En: Ius et Veritas, No. 35. Lima. p.75. Asimismo, Esteban Alva, haciendo referencia al pronunciamiento del Tribunal Constitucional contenido en los expedientes 6149-2006- 
siendo el debido proceso un derecho fundamental de contenido amplio, será posible que algunas de sus manifestaciones no sean susceptibles de ser invocadas en sede arbitral, dadas las particulares características que reviste esta jurisdicción de excepción ${ }^{\prime A O}$. En ese mismo sentido se pronuncia González de Cossío al señalar que:

"(...) incluye el derecho a que el procedimiento arbitral sea seguido en la forma establecida en el acuerdo arbitral y que tengan una oportunidad razonable de manifestar lo que a su derecho convenga o, utilizando las palabras del Código de Comercio, hacer valer sus derechos." ${ }^{\prime 1}$

El derecho de defensa pactado en el convenio arbitral o en el reglamento es un mecanismo de ejecución del contrato que puede ser regulado en el convenio. Y cuando las partes no regulan expresamente el detalle de las normas arbitrales pero sí se someten al reglamento de una institución, las partes están pactando que las normas que regularán la solución del conflicto son las de ese reglamento. Por tanto, mientras el arbitraje se haya tramitado respetando las reglas pactadas por las partes, no se configuraría esta causal. Este es el criterio con el que debe interpretarse el tema del derecho de defensa en materia arbitral. No obstante, en el caso peruano, debemos recordar que la Duodécima Disposición Complementaria del Decreto Legislativo 1071 establece que el recurso de anulación es la vía idónea para cuestionar la amenaza o vulneración de cualquier derecho constitucional durante la tramitación del arbitraje. Esta disposición permite que la parte interesada solicite la anulación invocando no sólo la afectación del derecho al debido proceso (que desde ya debía aplicarse restrictivamente) sino de cualquier otro derecho constitucionalmente protegido. Nos referiremos a esta peculiar causal de anulación cuando más adelante desarrollemos la sentencia 00142-2011-PA/TC del Tribunal Constitucional.

Si el Poder Judicial declara fundado el recurso de anulación por esta causal, los árbitros deberán reiniciar el arbitraje desde el momento en que se cometió la vulneración al derecho de defensa.

\subsection{La composición del Tribunal o las actuaciones arbitrales no se ajustaron al acuerdo o reglamento, o el laudo vulnera normas de orden público}

Según el artículo 63.1.c del Decreto Legislativo 1071, se podrá interponer recurso de anulación cuando:

PA/TC y 6662-2006-PA/TC, sostiene que "nuestro Tribunal Constitucional se cuidó de precisar que la manifestación o extensión de este derecho no puede ser idéntica dentro de un proceso judicial y uno arbitral". Alva Navarro, Esteban, La anulación de laudo, Palestra, Lima, 2011, p.149.

$40 \quad$ Alva Navarro, Esteban La anulación de laudo, Palestra, Lima, 2011, p.150.

41 González De Cossío, Francisco. "Arbitraje", Porrúa, México, 2011, p. 776. 
"(...) la composición del tribunal arbitral o las actuaciones arbitrales no se han ajustado al acuerdo entre las partes o al reglamento arbitral aplicable, salvo que dicho acuerdo o disposición estuvieran en conflicto con una disposición de este Decreto Legislativo de la que las partes no pudieran apartarse, o en defecto de dicho acuerdo o reglamento, que no se han ajustado a lo establecido en este Decreto Legislativo."

Esta causal está muy vinculada al convenio arbitral. Antes de iniciar las actuaciones arbitrales, las partes se ponen de acuerdo respecto a cuáles serán las reglas del procedimiento arbitral. Esto quiere decir que pueden elegir el número de árbitros, los requisitos y condiciones que deben reunir y la forma en que deben ser designados.

El acuerdo de las partes que regula las actuaciones arbitrales puede estar contenido en el convenio arbitral, en el Acta de Instalación del Tribunal Arbitral o en cualquier otro acto celebrado antes o durante el trámite del arbitraje. Asimismo, de acuerdo al artículo 6.b del Decreto Legislativo $1071^{42}$, el reglamento de arbitraje se considera parte del convenio arbitral. Por ello el incumplimiento del acuerdo o del reglamento sobre la composición del tribunal o las actuaciones arbitrales pueden llevar a que se anule el laudo. Se trata de una causal contractual que busca que se cumpla lo pactado por las partes. Por ello es una causal tipo II.

Si el Poder Judicial declara fundado el recurso de anulación por esta causa, las partes podrán nombrar a nuevos árbitros o, en su caso, el Tribunal Arbitral reiniciará el proceso arbitral en el estado en que no se observó el acuerdo de las partes, el reglamento o la ley.

\subsection{Laudar sobre materias no sometidas a decisión arbitral}

El artículo 63.1.d del Decreto Legislativo 1071 señala que procederá el recurso de anulación cuando los árbitros hayan resuelto sobre materias no sometidas a su decisión por las partes. Esto es consecuencia de que el arbitraje solo se activa cuando las partes deciden determinados conflictos al mecanismo previsto en la cláusula arbitral.

Dado que los árbitros cumplen la obligación de resolver el conflicto a partir de lo que las partes le plantean, aquellos sólo pueden pronunciarse sobre los que les ha sido encargado. Podría decirse que esta causal es muy similar a lo que en el Derecho

42 "Artículo 60.- Reglas de interpretación. Cuando una disposición de este Decreto Legislativo: (...)

b. Se refiera al convenio arbitral o a cualquier otro acuerdo entre las partes, se entenderá que integran su contenido las disposiciones del reglamento de arbitraje al que las partes se hayan sometido." 
Procesal Civil se conoce como vicios de incongruencia extra petita o ultra petita ${ }^{43}$. Ahora, si bien para Bullard existe una diferencia en la aplicación de estos conceptos pues en el caso de los jueces la fuente de limitación es el Código Procesal Civil mientras que para los árbitros la fuente de limitación es el convenio arbitral y las reglas aplicables a partir de tal convenio ${ }^{44}$, considero que el efecto práctico la anulación de los fallos por haber incurrido en incongruencia extra petita y ultra petita son exactamente los mismos en sede judicial y en sede arbitral. Por lo tanto, el tratamiento debería ser el mismo en ambas vías y los estudios arbitrales no deberían desdeñar las valiosas investigaciones que desde hace mucho tiempo han hecho los procesalistas sobre el tema.

Los árbitros pueden incurrir en errores de incongruencia como fallar más allá del petitorio o fallar sobre un tema no propuesto en las pretensiones. ¿Cuáles de estos errores son causales de anulación de laudo de acuerdo a la regulación peruana? Avendaño Valdez y Ledesma sostienen que solo los fallos extra petita y no los ultra petita. El primero considera que:

"La LA (sic) solamente comprende como causal de anulación de laudo, la primera de las modalidades antes mencionadas o sea cuando los árbitros fallan de más, lo que en doctrina se denomina incongruencia por exceso (...) el fundamento de este motivo es la falta de competencia o legitimación de los árbitros para conocer y resolver sobre cuestiones litigiosas que no le han sido encomendadas" ${ }^{\prime 45}$

43 Los fallos extra petita son aquellos en los que el juez se pronuncia sobre una pretensión no solicitada por el demandante mientras que los fallos ultra petita son aquellos en los que el juez otorga un monto mayor a lo solicitado en la demanda pero no agrega una nueva pretensión. Para Monroy Gálvez, estos fallos se generan a partir del incumplimiento del principio de congruencia en virtud del cual el juez no puede darle a una parte más de lo que esta pide: 'Siendo el juez la persona encargada de declarar el derecho que corresponda al caso concreto, y pese a que las normas que regulan el trámite que lo conducirá a producir dicha declaración son de naturaleza pública, el derecho que declara - nos referimos al contenido de su declaración - es de naturaleza privada, en consecuencia, le pertenece a las partes. Por tal razón, el juez civil no tiene la facultad para afectar la declaración de voluntad del pretensor (demandante) y concederle más de lo que este ha pretendido en su demanda. Sin embargo, este impedimento no se presenta cuando el juez le otorga menos de lo demandado, dado que tal declaración se habrá expedido cuando, por ejemplo, el juez estime que el demandante no probó todos los extremos de su pretensión." Monroy Gálvez, Juan, "Introducción al proceso civil". En: Temis, Bogotá, 1996, p. 91.

44 Bullard G., Alfredo, "¿Qué fue primero: el huevo o la gallina? El Carácter contractual del recurso de anulación". En: Revista Internacional de Arbitraje, Julio - Diciembre 2013, Lima, p. 88.

45 Avendaño Valdez, Juan Luis. Comentarios a la Ley Peruana de Arbitraje, Instituto Peruano de Arbitraje Comercial y Arbitraje de Inversiones - IPA, Lima, 2011, p. 705. 
Ledesma a su vez sostiene que "el cuestionamiento a la nulidad del laudo no se basa en pronunciamientos citra petita o ultra petita sino en cuestionamientos extra petita, esto es, laudos sobre materia no sometida a la decisión de los árbitros."

Por su parte, Cantuarias Salaverry y González de Cossío sostienen que esta causal se refiere a fallos extra petita y ultra petita. El primero señala que "esto significa que la causal bajo comentario afectará esencialmente a los laudos arbitrales que contengan excesos en la materia (extra petita o ultra petita), pero no cuando los árbitros fallen omitiendo resolver sobre alguna materia sometida a su conocimiento (infra petita). ${ }^{\prime 46}$

Asimismo, González de Cossío afirma lo siguiente:

"Si bien ambos términos se refieren, en esencia, al mismo fenómeno, puede hacerse una pequeña distinción: mientras que extra petita se refiere al caso en el que un tribunal arbitral ha realizado actividades que exceden en su totalidad el ámbito de aplicación del acuerdo arbitral, ultra petita se refiere a situaciones en las que el tribunal comenzó sus labores dentro de los límites del acuerdo arbitral pero terminó por excederlos.. ${ }^{\prime \prime 7}$

A mi juicio, esta causal debe permitir pretender la anulación tanto del laudo extra petita y ultra petita. Imaginemos que $A$ interpone una demanda de indemnización por daños y perjuicios contra $B$, donde la pretensión asciende a la suma de 15 . Pero luego el Tribunal Arbitral falla otorgando a $A$ una indemnización ascendente a 50 . En este ejemplo, nos encontramos ante un fallo ultra petita porque los árbitros han otorgado como indemnización un monto mayor al solicitado por el demandante; es por eso que a mi juicio la parte interesada podría solicitar la anulación del laudo por haber incurrido en la causal regulada.

Respecto del fallo extra petita, imaginemos que a partir de la demanda y reconvención de la demanda el objeto del arbitraje son los puntos controvertidos A, B y C, entonces los árbitros sólo podrán pronunciarse respecto a esos temas específicos. Pero si emiten un laudo pronunciándose sobre A, B, C y D, de conformidad con el artículo 58.1.d del Decreto Legislativo 1071, la parte interesada deberá solicitar la exclusión del extremo D resuelto en el laudo y solo si los árbitros no rectifican su error, podrá interponer un recurso de anulación.

Además, esta causal también permite solicitar la anulación del laudo que se pronuncia sobre una materia no prevista en el convenio arbitral. En ese sentido se pronuncia Avendaño Valdez citando a Cantuarias Salaverry:

"El contenido del laudo está delimitado por los puntos litigiosos que las partes sometieron a los árbitros quienes deben pronunciarse sobre todas

46 Cantuarias Salaverry, Fernando, Arbitraje comercial y de las inversiones, Universidad Peruana de Ciencias Aplicadas, Lima, 2007, p. 508. González De Cossío, Francisco, Arbitraje, Porrúa, México, 2011, p. 780. 
las cuestiones comprometidas sin poder extenderse a otras que las partes no han consentido en someterlas, el fundamento reside en el origen voluntario de la jurisdicción de los árbitros (...) para las cuestiones respecto de las cuales no existe pacto arbitral queda subsistente la jurisdicción de los tribunales estatales que no ha sido renunciada, careciendo los árbitros de facultades para resolverlas. Un laudo arbitral que recaiga sobre ellas importaría violentar la intención de las partes dando a la renuncia a los jueces del Estado una extensión no deseada." ${ }^{\prime \prime 8}$

Nos encontramos ante una causal que busca proteger que lo pactado en el convenio arbitral se respete. Es un mecanismo que sirve para tener certeza que la ejecución del convenio arbitral se realizó tal como las partes acordaron. Por eso se trata de una causal tipo II.

Si el Poder Judicial declara fundado el recurso de anulación por haberse pronunciado sobre materia no sometida a arbitraje, el conflicto puede ser objeto de un nuevo arbitraje si así estuviera contemplada en el convenio arbitral. Caso contrario, se podrá demandar judicialmente, salvo pacto distinto. Ahora, si tomamos nuevamente el ejemplo señalado en el párrafo precedente, la parte interesada solicita la exclusión del extremo $D$ resuelto en el laudo. Entonces, la pregunta que surge es ¿cuál es el alcance de la intervención del Poder Judicial respecto de la anulación del laudo? Al respecto, Fernando Cantuarias sostiene que:

"los artículos citados de la Ley General de Arbitraje peruana y de la Convención de Nueva York, expresamente, establecen que la anulación o el no reconocimiento, según corresponda, solo afectará los puntos no sometidos a decisión, siempre y cuando tengan sustantividad propia y no aparezcan inseparablemente unidos a la cuestión principal. ${ }^{\prime 49}$

En ese mismo sentido se pronuncia García Ascencios al señalar lo siguiente:

"Esta causal permite que las partes demanden la anulación del laudo respecto de la materia que no ha sido sometida a arbitraje. Por ello, la declaración de nulidad deberá ser únicamente ante las materias que no deberían arbitrarse, preservándose las que sí fueron sometidas a la vía arbitral $^{\prime \prime 50}$

Coincido con ambos autores cuando sostienen que sólo debería excluirse el extremo que no fue sometido a decisión del Tribunal Arbitral de manera que, respecto a las

48 Avendaño Valdez, Juan Luis, Comentarios a la Ley Peruana de Arbitraje, Instituto Peruano de Arbitraje Comercial y Arbitraje de Inversiones - IPA, Lima, 2011, p. 706.

49 Cantuarias Salaverry, Fernando, "Cuestiones generales aplicables a las causales de anulación de laudos arbitrales dictados en el foro y a las causales para no reconocer y ejecutar laudos arbitrales dictados en el extranjero". En: Themis. Revista de Derecho, No. 50, Lima, 2005, p. 508. 
demás pretensiones, el laudo sea válido y eficaz. Esto disminuiría los costos de iniciar un nuevo proceso arbitral a fin de corregir solo este exceso en el pronunciamiento.

\subsection{Materias no arbitrables}

El artículo 63.1.e del Decreto Legislativo 1071 señala que también es posible interponer recurso de anulación alegando lo siguiente: "(...) que el tribunal arbitral ha resuelto sobre materias que, de acuerdo a ley, son manifiestamente no susceptibles de arbitraje, tratándose de un arbitraje nacional."

El arbitraje se caracteriza por la libertad otorgada a las partes para decidir qué conflictos serán sometidos a la decisión de los árbitros, así como para establecer cuáles serán las reglas aplicables al arbitraje. Pero esa libertad no es absoluta. Recordemos que el convenio arbitral es un contrato mediante el cual las partes acuerdan someter determinados conflictos al fuero arbitral; por lo tanto, como cualquier contrato, el convenio arbitral está sujeto a lo establecido por las leyes de orden público. Estos límites a la libertad de las partes para someter sus conflictos al arbitraje, se establecieron en el artículo 2.1 del Decreto Legislativo 1071: "(...) pueden someterse a arbitraje las controversias sobre materias de libre disposición conforme a derecho, así como aquellas que la ley o los tratados o acuerdos internacionales autoricen".

La norma contempla dos supuestos sobre qué puede someterse a arbitraje: i) las materias de libre disponibilidad de acuerdo al ordenamiento legal vigente; y, ii) las materias autorizadas por un tratado o acuerdo internacional, así dichas materias sean no disponibles para el sistema jurídico peruano.

A diferencia de la antigua Ley General de Arbitraje $^{51}$ que establecía una lista de las materias expresamente susceptibles de ser sometidas a arbitraje, el Decreto Legislativo 1071 se limita a la norma general contenida en el artículo 2 y no precisa en qué casos específicos nos encontramos ante derechos disponibles y en qué otros frente a

$51 \quad$ El artículo $1^{\circ}$ de la antigua Ley 26572, Ley General de Arbitraje, establecía lo siguiente: "Pueden someterse a arbitraje las controversias determinadas o determinables sobre las cuales las partes tienen facultad de libre disposición, así como aquellas relativas a materia ambiental, pudiendo extinguirse respecto de ellas el proceso judicial existente o evitando el que podría promoverse; excepto:

1. Las que versan sobre el estado o la capacidad civil de las personas, ni las relativas a bienes o derechos de incapaces sin la previa autorización judicial.

2. Aquellas sobre las que ha recaído resolución judicial firme, salvo las consecuencias patrimoniales que surjan de su ejecución, en cuanto conciernan exclusivamente a las partes del proceso.

3. Las que interesan al orden público o que versan sobre delitos o faltas. Sin embargo, si podrá arbitrarse sobre la cuantía de la responsabilidad civil, en cuanto ella no hubiera sido fijada por resolución judicial firme.

4. Las directamente concernientes a las atribuciones o funciones de imperio del Estado, o de personas o entidades de derecho público. 
derechos indisponibles. Es por ello que surge la necesidad de interpretar y delimitar, en la medida de lo posible, el alcance de este concepto. Para Avendaño Valdez, no existe un acuerdo en la doctrina respecto al concepto de materia disponible por lo que sostiene lo siguiente:

"Me inclino por dejar al margen del arbitraje, tanto para el Estado como para los particulares, aquellos conflictos que versen sobre normas imperativas, en las cuales la libertad o autonomía contractual está absolutamente limitada. Si la esencia del arbitraje es la autonomía de la voluntad y ésta choca contra una norma imperativa, es evidente que estamos frente a un caso de inarbitrabilidad. ${ }^{\prime 52}$

Asimismo, Ledesma señala que:

"El consentimiento expreso o tácito de las partes a lo laudado no puede convalidar lo inarbitrable de la materia por afectar el orden público, entendido este como el conjunto de normas imperativas a las que la autonomía de la voluntad no puede descartar. ${ }^{\prime 153}$

En mi opinión, la libertad de las partes no es absoluta sino que se debe sujetar a lo dispuesto por las normas imperativas. Es por ello que la discusión en esta causal se refiere a si el convenio arbitral respetó la ley y se arbitró sobre aquello que está permitido; por lo tanto, nos encontramos ante una causal tipo I.

\subsection{Contra orden público internacional o materia no apta de arbitraje internacional}

Según el artículo 63.1.f del Decreto Legislativo 1071, se puede interponer recurso de anulación si "según las leyes de la República, el objeto de la controversia no es susceptible de arbitraje o el laudo es contrario al orden público internacional, tratándose de un arbitraje internacional."

Esta causal se refiere a los laudos emitidos ya no en arbitrajes nacionales sino en arbitrajes internacionales. El objeto de la regulación es el mismo que el señalado en el artículo 63.1.e del Decreto Legislativo 1071, ya que el concepto de orden público internacional le da un carácter más general y flexible a lo que es arbitrable. García Ascencios sostiene que el orden público internacional es un concepto elástico, cambiable, de difícil conceptualización y que debería ser interpretado restrictivamente ${ }^{54}$. Por su parte, Cárdenas Mejía considera que el orden público

52 Avendaño Valdez, Juan Luis, Comentarios a la Ley Peruana de Arbitraje, Instituto Peruano de Arbitraje Comercial y Arbitraje de Inversiones - IPA, Lima, 2011, p. 710.

53 Ledesma Narváez, Marianella, Jurisdicción y Arbitraje, Fondo Editorial PUCP, 2da.Ed., Lima, 2010, p.174.

54 García Ascencios, Frank. Amparo versus Arbitraje. Improcedencia del amparo contra laudos arbitrales. Adrus, Lima, 2012, p. 65. 
internacional puede tener un triple origen: i) los principios básicos del ordenamiento que no pueden dejar de aplicarse en situaciones internacionales, ii) las leyes de policía (orden público) que se aplican en situaciones internacionales y iii) las obligaciones internacionales entre los estados ${ }^{55}$.

En consecuencia, nos encontramos ante una causal que busca definir qué puede ser objeto del convenio arbitral y su ejecución; es decir, si el convenio arbitral excedió lo establecido por las normas internacionales. Se trata de una causal tipo I.

\subsection{Laudo fuera del plazo}

Por último, el artículo 63.1.g del Decreto Legislativo 1071 establece que es procedente el recurso de anulación cuando "la controversia ha sido decidida fuera del plazo pactado por las partes, previsto en el reglamento arbitral aplicable o establecido por el tribunal arbitral."

Entre los aspectos sobre los que las partes tienen libertad de pactar las reglas del arbitraje, está el plazo otorgado a los árbitros para emitir el laudo. Si los árbitros no emiten el laudo dentro del plazo señalado por las partes, ya sea que haya sido fijado en el mismo convenio, por remisión al reglamento o fijado por los propios árbitros de acuerdo a lo que las partes se lo permitieron, se puede interponer un recurso de anulación. Recordemos que el artículo 53 del Decreto Legislativo 1071 establece que la controversia debe decidirse y notificarse dentro del plazo establecido por las partes, por el reglamento o por el Tribunal Arbitral. Por lo tanto, si el laudo se emite dentro del plazo pero es notificado a las partes fuera de éste, la parte interesada podrá interponer recurso de anulación alegando esta causal. Al respecto, Avendaño Valdez sostiene que $^{56}$ :

"El fundamento de esta causal es la falta de jurisdicción del tribunal arbitral. Vencido el plazo, a diferencia de lo que sucede con los jueces ordinarios, los árbitros pierden su capacidad para decir el derecho. Por tanto, un laudo expedido fuera de plazo habrá sido dictado por tres ciudadanos que por el transcurso del tiempo perdieron la capacidad para dirimir la controversia, o sea para laudar."

Nos encontramos ante la discusión contractual de si se cumplió o no con lo establecido en el convenio arbitral, por lo que se trata de una causal tipo II.

Si el Poder Judicial declara fundado el recurso de anulación de laudo por haber sido emitido fuera del plazo, las partes pueden iniciar un nuevo proceso arbitral. Existe

55 Avendaño Valdez, Juan Luis, Comentarios a la Ley Peruana de Arbitraje, Instituto Peruano de Arbitraje Comercial y Arbitraje de Inversiones - IPA, Lima, 2011, p. 713.

56 Avendaño Valdez, Juan Luis, Comentarios a la Ley Peruana de Arbitraje, Instituto Peruano de Arbitraje Comercial y Arbitraje de Inversiones - IPA, Lima, 2011, p. 714. 
también la posibilidad que las partes acuerden nombrar a un nuevo Tribunal Arbitral a fin de que éste resuelva la controversia sobre la base de las actuaciones del arbitraje existente; o, tratándose de un arbitraje nacional, las partes pueden decidir que la Corte que conoció el recurso de anulación resuelva en única instancia el fondo de la controversia.

\subsection{Afectación constitucional}

Además de las causales reguladas en el artículo 63.1 del Decreto Legislativo 1071, la Duodécima Disposición Complementaria de dicho cuerpo legal establece a mi juicio una de anulación de laudo adicional:

"DUODÉCIMA. Acciones de garantía.- Para efectos de lo dispuesto en el inciso 2 del artículo 5 del Código Procesal Constitucional, se entiende que el recurso de anulación del laudo es una vía específica e idónea para proteger cualquier derecho constitucional amenazado o vulnerado en el curso del arbitraje o en el laudo."

En el Perú el recurso de anulación de laudo, y no el proceso de amparo, es la vía idónea para cuestionar la vulneración de un derecho constitucional, ya sea que se haya producido durante el trámite del arbitraje o en el laudo. Esto significa que si el Poder Judicial resuelve que no hubo amenaza ni vulneración de ningún derecho constitucional en el arbitraje o en el laudo, luego de interponerse un recurso de anulación, es improcedente una demanda amparo contra el laudo. Esto implica también que el recurso de anulación no es una vía previa para la interposición de una demanda de amparo.

El modo cómo se debe invocar esta causal no está aún muy definido en la práctica judicial, al punto que algunos colegas piensan que debe encajar inevitablemente en algunas de las causales taxativas del artículo 63.1 del Decreto Legislativo 1071. A mi juicio, por más que sea totalmente perjudicial para consolidar la institución del arbitraje en el Perú e ir directamente contra el principio de inevitabilidad del arbitraje, la Duodécima Disposición Complementaria del Decreto Legislativo 1071 estaría regulando una causal independiente de las taxativas del artículo 63.1, de modo además que es excesivamente abierta y permitiría, según lo dispuesto por el mismo Tribunal Constitucional, anular incluso el fondo de lo laudado por afectación de cualquier derecho constitucional más allá del debido proceso. Veamos ahora cómo han ido cambiando las disposiciones del Tribunal Constitucional sobre la afectación de derechos constitucionales en un arbitraje.

En la sentencia recaída en el expediente 6167-2005-PHC/TC, el Tribunal Constitucional estableció inicialmente como precedente vinculante que el control constitucional del laudo arbitral solo era procedente si se alegaba la vulneración del derecho a la tutela jurisdiccional efectiva o si se advertía el incumplimiento, por parte de los propios 
árbitros, de la aplicación de la jurisprudencia constitucional o los precedentes de observancia obligatoria.

Luego, en la sentencia recaída en el expediente 4972-2006-PA/TC, el Tribunal Constitucional aclaró que se podía cuestionar el laudo arbitral cuando éste vulnere o amenace cualquiera de los componentes del derecho a la tutela jurisdiccional efectiva o aquellos derechos que integran el derecho al debido proceso ya sea en su dimensión formal o en su dimensión material. Es decir, la parte interesada podía cuestionar el laudo arbitral alegando la vulneración del derecho de acceso a la jurisdicción, derecho de defensa, derecho a la debida motivación, derecho a obtener una decisión que siga estándares de razonabilidad y proporcionalidad, entre otros. En la misma línea, en la sentencia recaída en el expediente 04195-2006-AA/TC, el Tribunal Arbitral estableció que el amparo es improcedente cuando se cuestione la interpretación realizada por el Tribunal Arbitral respecto a normas legales, siempre que de tales interpretaciones no se desprenda un agravio manifiesto a la tutela procesal o al debido proceso.

Finalmente, en la Sentencia 00142-2011-PA/TC, el Tribunal Constitucional estableció como precedente vinculante cuándo es improcedente una demanda de amparo contra un laudo arbitral:

- Si la parte interesada pretende alegar la amenaza o vulneración de sus derechos constitucionales, el recurso de anulación constituye la vía procedimental específica igualmente satisfactoria para la protección de dichos derechos. En estos casos no es procedente el amparo contra laudo.

- Si la parte interesada pretende alegar la vulneración de derechos fundamentales relacionados con el debido proceso o la tutela jurisdiccional efectiva, la vía idónea para hacerlo, de conformidad con el artículo 63.1.b del Decreto Legislativo 1071, es el recurso de anulación. Acá tampoco será procedente el amparo contra laudo.

- Si la parte interesada pretende cuestionar la falta de convenio arbitral, la vía idónea para hacerlo, de conformidad con el artículo 63.1.a del Decreto Legislativo 1071 es el recurso de anulación. El amparo contra laudo será declarado improcedente. No obstante, a mi juicio este supuesto es muy cuestionable cuando estamos ante el supuesto de arbitrajes fraudulentos. Es decir, aquellos donde a sabiendas de que no hay convenio arbitral, una de las partes (o ambas) se ponen de acuerdo con los árbitros para perjudicar a la otra parte (o a un tercero). En estos casos resulta absurdo que la parte perjudicada tenga que esperar a que finalice el arbitraje fraudulento para plantear el recurso de anulación, con el consiguiente riesgo de medidas cautelares en su contra durante la tramitación del arbitraje fraudulento.

- Si la parte interesada pretende alegar que, a pesar de haber aceptado voluntariamente la jurisdicción arbitral, las materias sobre las que se ha decidido 
tienen que ver con derechos fundamentales de carácter indisponible, la vía específica es también el recurso de anulación.

- Sólo será procedente la demanda de amparo si la resolución judicial que resuelve el recurso de anulación de laudo vulnera derechos constitucionalmente protegidos. Por ejemplo, si la resolución judicial que resuelve el recurso de anulación está motivada arbitrariamente o fue dictada sin emplazar al demandado, el afectado puede interponer una demanda de amparo contra dicha resolución judicial. En dicho proceso constitucional, por cierto, no podrá discutirse tema alguno referido al laudo, ya que, siguiendo los mismos ejemplos, la consecuencia de un amparo fundado será solo anular la resolución judicial de modo que se motive debidamente o que se emplace al demandado y se reanude el trámite del recurso de anulación.

En esta misma sentencia, el Tribunal Constitucional determinó cuáles sí son los supuestos de procedencia del amparo contra laudos:

- Si la parte interesada alega la vulneración directa de los precedentes vinculantes establecidos por el Tribunal Constitucional, el amparo será procedente siempre que se haya interpuesto reclamo ante los árbitros como vía previa.

- Si la parte interesada alega que en el laudo se ha ejercido control difuso sobre una norma declarada constitucional por el Tribunal Constitucional o el Poder Judicial, la demanda de amparo será procedente siempre que se haya interpuesto reclamo ante los árbitros como vía previa.

- Si la parte interesada es un tercero que no forma parte del convenio arbitral y sustenta que el laudo afecta directamente sus derechos constitucionales, el amparo será procedente salvo que en aplicación del artículo 14 del Decreto Legislativo 1071, el convenio arbitral le sea extendido.

Esta norma dispone que "El convenio arbitral se extiende a aquellos cuyo consentimiento de someterse a arbitraje, según la buena fe, se determina por su participación activa y de manera determinante en la negociación, celebración, ejecución o terminación del contrato que comprende el convenio arbitral o al que el convenio esté relacionado. Se extiende también a quienes pretendan derivar derechos o beneficios del contrato, según sus términos." Bullard sostiene que esta norma "refleja la naturaleza contractual del convenio, y busca definir diversas formas en que se puede entender que las partes han consentido el mismo, se aleja, por tanto, de una concepción procesal según la cual se pueden incorporar terceros a un proceso arbitral porque estamos frente a una jurisdicción ${ }^{57 \prime \prime}$.

57 Bullard G., Alfredo, Comentarios a la Ley Peruana de Arbitraje, Instituto Peruano de Arbitraje Comercial y Arbitraje de Inversiones - IPA, Lima, 2011. p. 203. 
El artículo no dispone que se incorpore a un tercero propiamente dicho al arbitraje. Quien ingresa en realidad al arbitraje es una parte no signataria del convenio arbitral que por su participación en la negociación, celebración y ejecución del contrato que lo contiene, sí puede ser parte del arbitraje. Esta regulación no establece requisitos formales a fin de que el sujeto no signatario forme parte del proceso. Basta que de sus actos se desprenda que tenía conocimiento del contenido del convenio arbitral y que obtenía derechos y beneficios del contrato para que forme parte del arbitraje. Por ejemplo, se podría aplicar cuando el convenio arbitral es firmado por una empresa $\mathrm{X}$, pero resulta que el único beneficiario y a la vez único ejecutor de las prestaciones del contrato es la empresa subsidiaria de X llamada Y.

Respecto a este supuesto de procedencia de amparo contra laudo arbitral, en la sentencia recaída en el expediente 03841-2012-PA/TC, el Tribunal Constitucional declaró fundada la demanda de amparo interpuesta por el accionista de una empresa a fin de garantizar sus derechos al debido proceso, defensa y propiedad pues la ejecución de un laudo afectaba sus derechos patrimoniales sobre un inmueble. El Tribunal Constitucional señaló que: "resulta evidente que en el proceso arbitral seguido entre SACIP y Flotal Construcciones Logística y Servicios S.A.C. se ha resuelto sobre aspectos relacionados a los derechos del demandante, principalmente del derecho de propiedad, en tanto que el laudo arbitral dispone de algunos de sus atributos (uso y goce) sin que el demandante haya formado parte del convenio arbitral. En efecto, el demandante no es parte del convenio arbitral, ni del proceso arbitral, pero a pesar de ello se dispuso de algunos atributos de su derecho de propiedad y se le pretende ejecutar los efectos del laudo arbitral, razones por las cuales corresponde estimar la demanda." Si el Tribunal Arbitral hubiese aplicado el artículo 14 del Decreto Legislativo 1071 y hubiera extendido el convenio arbitral al accionista de la empresa para que participe del arbitraje como parte no signataria, se ahorrarían los costos de iniciar y tramitar el proceso de amparo y lo decidido en el laudo sería eficaz para todos los que participaron en el Arbitraje. El costo de tramitar un proceso de amparo contra laudo arbitral es mayor al beneficio que se obtiene de aplicar el artículo 14 del Decreto Legislativo 1071 y extender el convenio arbitral a partes no signatarias cuando sea válidamente aplicable.

Para finalizar, si se declara fundada la demanda de amparo por alguno de estos últimos tres supuestos establecidos por el Tribunal Constitucional, el laudo puede ser

En ese mismo sentido se pronuncia Sabroso: "Resulto (sic) oportuno precisar que el referido artículo 14 no debe ser leído como si su intención fuera introducir un tercero en el proceso arbitral, sino que ésta es una parte no signataria, a quien se incorpora al arbitraje porque de algún comportamiento suyo se desprende su aceptación del convenio arbitral." Sabroso Minaya, Rita, "Algunas reflexiones en torno a las partes no signatarias del convenio arbitral". En línea: http://enfoquederecho.com/algunas-reflexiones-entorno-a-las-partes-no-signatarias-del-convenio-arbitral/, Fecha de Consulta: 28/02/2014. 
anulado en forma total o parcial. Se podrá ordenar la emisión de un nuevo laudo que reemplace al anterior o a la parte que fue anulada, bajo los criterios señalados en la respectiva sentencia. No obstante, en ningún caso, el juez o el Tribunal Constitucional podrán resolver sobre el fondo de la controversia sometida a arbitraje. 